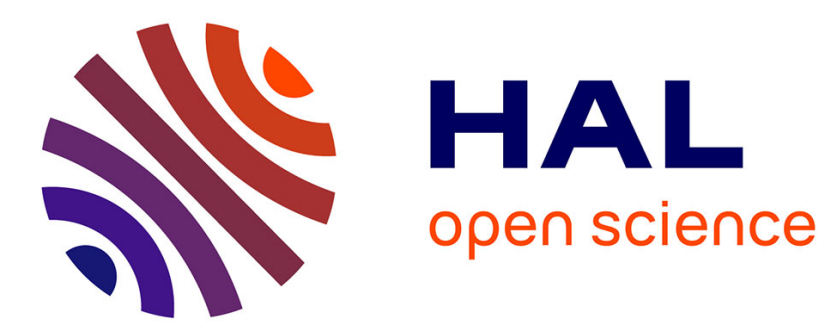

\title{
Modeling the impact of real and financial shocks on Mercosur: the role of the exchange rate regime
}

\author{
Jean-Pierre Allegret, Alain Sand-Zantman
}

\section{To cite this version:}

Jean-Pierre Allegret, Alain Sand-Zantman. Modeling the impact of real and financial shocks on Mercosur: the role of the exchange rate regime. 2007. halshs-00142506

\section{HAL Id: halshs-00142506 \\ https://shs.hal.science/halshs-00142506}

Submitted on 19 Apr 2007

HAL is a multi-disciplinary open access archive for the deposit and dissemination of scientific research documents, whether they are published or not. The documents may come from teaching and research institutions in France or abroad, or from public or private research centers.
L'archive ouverte pluridisciplinaire $\mathbf{H A L}$, est destinée au dépôt et à la diffusion de documents scientifiques de niveau recherche, publiés ou non, émanant des établissements d'enseignement et de recherche français ou étrangers, des laboratoires publics ou privés. 
W.P. 07-01

\title{
Modeling the impact of real and financial shocks on Mercosur: the role of the exchange rate regime
}

\author{
Jean-Pierre Allegret, Alain Sand
}

Janvier 2007

GATE Groupe d'Analyse et de Théorie Économique UMR 5824 du CNRS

93 chemin des Mouilles - 69130 Écully - France

B.P. 167 - 69131 Écully Cedex

Tél. +33 (0)4 72866060 - Fax +33 (0)4 72866090

Messagerie électronique gate@gate.cnrs.fr

Serveur Web : www.gate.cnrs.fr 


\title{
Modeling the impact of real and financial shocks on Mercosur: the role of the exchange rate regime
}

\author{
Jean-Pierre Allegret ${ }^{1}$ \\ Alain Sand-Zantman ${ }^{2}$
}

First draft: December 2006

\begin{abstract}
:
This paper studies to what extent the diversity of exchange rate regimes within Mercosur exerts an influence on the feasibility of a monetary union in this area. A semi-structural VAR model is built for each country, including a set of international and domestic variables. Based on impulse response functions and forecast error decomposition, we conclude that differences of exchange rate regime explain significantly the divergences of economic dynamics triggered by foreign or domestic shocks. Second, we decompose the structural innovations generated by each country model into unobservable common and idiosyncratic components, using a statespace model. This last exercise, intended to assess the degree of policy coordination between the Mercosur members, did not disclose any common component for the structural innovations generated by the three national models.
\end{abstract}

Key-words : Business Cycles, OCA, Co-movement, VAR, Unobserved components model, Mercosur.

JEL Classification: C32, E32, F42.

\footnotetext{
1. GATE (UMR 5824 CNRS) and University Lumière Lyon2, allegret@gate.cnrs.fr

2. Corresponding author, (GATE, UMR 5824 CNRS), OFCE-FNSP, University Lumière Lyon2, ENS-LSH, a.sand@ens-lsh.fr.
} 


\section{Introduction}

The Common market of the South (Mercosur) was created in 1991 by the Treaty of Asuncion signed between Argentina, Brazil, Paraguay and Uruguay. At the beginning the formal project was just a free trade agreement. During the 90s, the signatory countries envisaged a more ambitious economic and monetary process of integration. The Mexican (1994), Asian (1997), Russian (1998), Brazilian (1999) and Argentina (2001-2002) crises strongly increased the volatility of the macroeconomic variables. In the face of shocks, economies gave priority to national concerns, weakening the economic and institutional links embodied in the Asuncion Treaty.

This evolution raises the question of the feasibility of a regional monetary union between the Mercosur countries ${ }^{3}$. The basic Optimal Currency Areas (OCA) literature identifies criteria to determine the appropriate domain -the optimal size- of a currency area. Countries can optimally form a monetary union when they fulfill the following criteria: (i) a high factor mobility; (ii) a high degree of trade; (iii) a strong symmetry of shocks explained by the diversified composition of output and trade; (iv) a high degree of financial integration; and (v) a high degree of similarity in preferences between member countries of the currency area. Eichengreen (1998), Levy-Yeyati and Sturzenegger (2000), Larrain and Tavares (2003), and Eichengreen and Taylor (2004) used the OCA theory to determine if Central and Latin American countries can choose a monetary union as their exchange rate regime. Their conclusion -using cross-section or panel data (as econometric methodology)- is that Mercosur countries are far from achieving the pre-requisites to constitute an OCA. From this point of view, Latin American countries (LAC) differ from other regions such as East Asia.

Alesina and Barro (2002) analyse currency unions in terms of costs and benefits. They distinguish two benefits: first, trade benefits - where the higher the bilateral trade the higher the gains linked to the reduction of transaction costs after adopting a common currency - and, second, the benefits of commitment (where the irreversibility of the currency union leads to a decrease in inflation). The main cost of a currency union is the loss of independent monetary policy. This cost increases with the importance of asymmetric disturbances across potential members of the union. Alesina, Barro, and Tenreyro (2003) have tested this model using annual data of bilateral trade, inflation rates, comovements of prices and output over the period 1960-1997. They show that the US dollar is not a good anchor for Mercosur countries. Co-movements of prices and outputs with the United States are weak. This result is particularly striking for the two main countries of this area: Argentina for which neither the US Dollar nor the Euro are natural anchors and Brazil for which the European currency is a more appropriate anchor.

Contrary to what OCA theory and cost-benefit analysis of a monetary union propose, our approach is exclusively based on the business cycle properties of the Mercosur countries. Our analysis focuses on

\footnotetext{
${ }^{3}$. For date availability reason, our study covers only three countries : Argentina, Brazil, and Uruguay.
} 
business cycles synchronization across countries, on the propagation mechanisms of shocks, and on their common and specific components.

Our paper raises several questions linked to the feasibility of a currency union in Mercosur. First, to what extent has the adoption of different exchange rate regimes affected the countries' reactions to disturbances? In other words, is the diversity of exchange rate regimes inside the area an obstacle to macroeconomic policy coordination? Different adjustments to similar external and/or domestic shocks give indications onto the degree of coordination between Mercosur countries. Second, what is the respective share of common and specific components of disturbances in the studied countries? Weak common components imply large exchange rate adjustments decreasing the feasibility of a currency union. They result either from the existence of asymmetric shocks across countries or from the absence of macroeconomic policy coordination. Third, taking into account the strong sensibility of LAC to boom-bust cycles in international capital markets, we try to determine to what extent international financial disturbances influence their business cycles.

A large body of empirical research focusing on the cyclical properties of Mercosur countries has been published. A first strand of literature uses different specifications to decompose cycles in specific and common components. Karras (2003) analyses real output fluctuations for Central and Latin American countries and for Canada with annual data over the period 1950-1997. The decomposition reveals that country-specific shocks in the Americas are both large and asynchronous. These countries are not an OCA. Using panel data econometrics, Loayza, Lopez, and Ubide (1999) build an error components model to estimate which fraction of annual real value-added growth in a given country can be attributed to country-specific factors - such as factor endowments or economic policies - or to common factors affecting all sectors and countries in a similar fashion, such as a financial crisis. The higher the proportion of variability in output growth rates explained by common factors -that is by country-independent factors- the higher the integration across countries is. For the period 1970-1994, the authors find that country-specific factors are dominant both in the short and long terms. A second strand of literature takes into account a larger macroeconomic framework with VAR or VECM models. Hallwood, Marsh, and Scheibe (2004) use a bivariate VAR system in first difference applied to Mercosur countries. With quarterly data on output and price levels spanning the period 1980-2002, they find no common pattern of shocks. The low correlation of shock-disturbances between Mercosur countries and the United States suggests that dollarization of the region is not a good solution. Using a dynamic panel setting with annual data over the period 1983-1999, Ahmed (2003) analyzes the fluctuations in the main LAC. Two results are especially important. On one hand, LAC do not have real common shocks with their main trade partners, including the United States. On the other hand, US three month real interest rate shocks explain a significant share of output fluctuations in these countries. A currency union with the United States would increase the monetary and financial effects of real shocks affecting the US economy: as a result, output fluctuations in LAC would increase. Fanelli and González-Rozada (2003) apply a bivariate structural VAR model in first difference - 
including quarterly date on a GDP and a combined prices index over the period 1980-2003- to identify the cycles and the coordination evidences within Mercosur. They deemed "symmetry" of shocks and try to shed some light on their sources. The authors try also to identify the common and specific components of domestic cycles, a question in focus in our paper. The results show that co-movements of shocks are weak; a similar trend is observed for the common component of disturbances.

Our paper differs from the previous literature on several points. First, our analysis focuses on the period following the creation of Mercosur. Indeed, not only the quality of data for long periods is low in emerging countries, but during the 80 s the three economies were very instable, mainly due to the debt crisis and the bouts of hyperinflation: such disturbances make data processing very complex and unstable. So, our study begins in 1991 by taking into account more stabilized economies. Our approach of currency unions being based on business cycle dynamics, we use quarterly data which are only available and comparable since 1990 for the three countries. As a result, the paper uses quarterly frequency for the period 1991-Q1-2006-Q1. Second, we build a semi-structural VAR including more macroeconomic variables than previous studies. In comparison of works which decompose shocks only into their specific and common components, we are able to identify the nature of disturbances hitting these countries. At the opposite of bivariate VAR models, we take into account more diverse shocks such as external and domestic disturbances, but also policy shocks. The convergence of the policy-mix is one of the main pillars of an optimal monetary union, especially in its endogenous dimension. Third, the semi-structural VAR includes the EMBI spreads ${ }^{4}$ as an international financial. There is an abundant literature stressing, on one hand, the influence of external factors on capital inflows into emerging markets (Calvo, Leiderman, and Reinhart (1993); Fernández-Arias (1995); Bruner, and Rigobon (2004)), and, on the other hand, the destabilizing influence of these inflows on macroeconomic fluctuations in these countries (Calvo (2005)). In addition, several empirical studies dedicated to the effects of shocks originated from the United States show that financial transmission via monetary policy shocks- exerts a stronger influence than real transmission on LAC output variability ${ }^{5}$.

Few papers dedicated to the OCA take into account the EMBI in their analysis. Fanelli and GonzálezRozada (2003) show that spreads exert a significant and negative influence on the common component of cycles in Mercosur countries. Berg, Borensztein, and Mauro (2002) question if LAC are frequently hit by large and common financial shocks. A positive answer could imply that monetary and exchange rate policies should react in a similar way in each country. As a result, a monetary union might be

\footnotetext{
4. EMBI measures yield spreads (over 'safe' or 'risk free' assets which bear minimal credit risk) on emerging market countries' debt instruments. The spread is the extra return required to compensate the investor for the additional risks faced when investing in emerging economies rather than in a 'safe asset' (such as a US government bond). EMBI measures the sovereign risk. Spreads increase with the deterioration -effective or expected- of fundamentals in the countries issuing bonds; they also increase in periods of international financial strains.

5 . See Carrera, Féliz, Panigo, and Saavedra (2002) for Argentina over the period 1991-1999 and Canova (2005) for a sample of central and Latin American countries over the period 1990-2002.
} 
appropriate. The authors use a correlation matrix to identify the common components of all domestic spreads $^{6}$. Their main result is that the degree of co-movements of financial variables is not higher among LAC than it is among other emerging markets. Uribe and Ye (2006) build a VAR system based on panel data set with seven emerging countries covering the period 1994-2001 at a quarterly frequency to analyze the respective influence of US interest rates and EMBI shocks on the macroeconomic fluctuations. An important finding is that EMBI shocks exacerbate the US interest rate shocks, implying a strong macroeconomic volatility in the studied emerging countries.

Last but not least, we propose to break down structural innovations of domestic semi-structural VAR into unobservable common and idiosyncratic components using a state-space model (Harvey, 1990). These models respond to the drawbacks of the previous literature of which the quasi-totality concentrates on the correlation of shocks without disaggregating the shocks in specific common and components constituent in every country. These results are used to check evidence of economic synchronicity, and convergence of macroeconomic policy

The remainder of this paper is organized as follows. Section two presents the outcomes of the estimates of a semi-structural VAR model for each economy; it identifies the interdependence between domestic macroeconomic variables and to external ones, and the sources of disturbances. Section three uses a state-space model to estimate to what extent the shocks -and especially macroeconomic policy shocks- have a common component allowing for speculation about coordination between Mercosur countries. Section four concludes.

\section{A semi-structural VAR model for the "Mercosur"}

Literature on regional integration and OCAs stresses the identification of common shocks, the degree of similarity in the adjustment process of the candidates and the convergence of policy responses to shocks. This section aims at deepening these points.

In the context of strong links of macroeconomic variables with complex feedback linkages, the Vector autoregression (VAR) approach constitutes a useful tool, allowing to capture the evolution and the interdependences between multiple time series. All the variables are treated symmetrically, including for each variable an equation which explains its evolution based on its own lags and the lags of all the other variables in the model. Sims (1980) advocates the use of unrestricted VAR models as a theoryfree method to estimate economic relationships: contrary to the structural method based on the choice of a particular model, this procedure embodies alternative theories "nested" in the empirical model".

\footnotetext{
${ }^{6}$. They first regress each individual country's spread series in the overall EMBI+ spread series, and save the residuals. Second they report the correlation matrix among these country-specific components of the spread series.

${ }^{7}$ As indicated in Canova (1995), the analyst's prior knowledge is used only to decide what variables should enter the reduced form and, in some cases, the time series transformations to be used (log or ratios of variables).
} 
The VMA (vector moving average) representation of the reduced form allows us to express the current and past values of the shocks, to trace out their time path on the variables contained in the VAR system, and to compute the impact multipliers (deduced from the impulse response functions). The forecast error variance decomposition indicates the proportion of the movement in a sequence due to its "own” shocks versus shocks to the other variables ${ }^{8}$. Thus, the convergence of evidence revealed by the tests, the impulse response functions, the forecast error variance decomposition and other forecasting properties give us some guidelines to choose between alternative theories. One of the main issues of these experiments comes from the identification of shocks. If the error terms of the VAR reduced form are correlated, there is no simple way to unambiguously identify shocks with specific variables, for the errors will have common components that affect more than one variable. The practitioner will have to attribute the effects of common components to one specific variable... biasing the interpretation of the impulse responses or of the forecast error variance decomposition: in short, the choice of procedure of identification, i.e. the procedure of shocks orthogonalization, must be based on some "a priori" knowledge. The Cholesky ordering is the usual and least theoretical method to orthogonalize shocks (this kind of "half" structural VAR is usually called either recursive VAR or RVAR, or, as in Doan, 2004, semi-structural VAR or SSVAR): however, the ordering is not really arbitrary, based on theoretical intuition. Another way is to introduce theory in these "a-theoretical" VAR models by the inclusion of theoretical restrictions in the "structural" VARs (SVARs).

We choose a recursive "Semi-Structural" approach for a VAR in difference. The former choice is justified below; the later one - a VAR in difference - is deduced from the Johansen test results, pointing out the lack of empirical support in favor of any cointegrating vector between the selected endogenous variables ${ }^{9}$.

\section{Variable selection $^{10}$}

Our choice of variables is the traditional one for VARs analyzing external shocks, and macroeconomic packages in open economies (Favero (2001), Lütkepohl and Krätzig (2004)). For the external variables, we chose (i) the Industrial Product Index of Industrialized Economies (noted I_IPI), and (ii) the Emerging Economy spread index of J.P. Morgan $(E M B I)^{11}$, a way to account for the main real

\footnotetext{
${ }^{8}$ Look at Enders (2004), for a very didactical explanation.

${ }^{9}$ In this case, Allen, P.G., and Fildes, R., (2004) showed that any alternative solutions - VAR in level, or VECM - would lead to greater forecast errors.

${ }^{10}$ All data are quarterly and proceed from the International Financial Statistics (IMF) except the EMBIs published by the Ministery of Economy and Production of the Republic of Argentina (http://www.mecon.gov.ar/peconomica/basehome/infoeco_ing.html) and the IPI Uruguayan published by the Central Bank of the Republic of Uruguay (http://www.bcu.gub.uy/).

${ }^{11}$ We merged two time series: the EMBI for the period 1991Q1-1997Q4 and the EMBI+ from 1998Q1. As indicated in Cunningham (1999), the main differences between these indices are (i) the number of financial instruments embodied (the EMBI tracks returns and spreads on Brady Bonds and some other restructured sovereign debts, the EMBI+ tracks returns on a wider range of instruments), (ii) the number of countries ( 11 for the EMBI, 16 for the EMBI+). However, in both the indices the weight of the LAC (Latin American countries) is very important (respectively $83.8 \%$ and $70.2 \%$ ). Amongst the LAC, both Argentina and Brazil weight $47.6 \%$ of
} 
supply and financial shocks. For the domestic variables (noted for each country “i”, $I=A, B, U$ ), we took Industrial Product Index (i_IPI), Consumption Prices Index (i_CPI), the nominal money market interest rate $\left(i \_R\right)^{12}$ and the direct quotation of the nominal foreign exchange rate with the US $\$$ as base currency (i_EN).

We begin by checking - for each country - the stationarity of the interest rates and the EMBI, and of the logarithm of all the other variables. Standard Augmented Dickey Fuller tests are largely perturbed by numerous shocks, periods of high inflation, stabilization programs, and change in monetary, currency, or fiscal regimes. But even after correction of structural breaks (Perron (1989)), all data are $\mathrm{I}(1)$, except interest rates and EMBI which are apparently $\mathrm{I}(0)$. As explained above, tests of cointegration (Johansen) failed to find any cointegrating vector ${ }^{13}$. Anyway, given the size of our data sample, the robustness test for stationnarity and cointegration are likely to be weak: we therefore followed economic theory to guide our choices.

Amongst the available procedures to identify innovations, we did not chose an SVAR methodology. First, assuming a long term neutrality of nominal shocks would seem widely arbitrary for a work covering about twelve or so years, even if business cycles are shorter for these countries than for the industrialized ones ${ }^{14}$. So, contrary to numerous similar works, we don’t apply the "BQ” decomposition identification procedure based on long run restrictions (Blanchard and Quah (1989)) ${ }^{15}$. Second, the inspection of the contemporary correlation matrix of the reduced form residuals (see appendix 1) doesn't justify the rejection of a recursive factorization based on a lower triangular matrix in order to identify the short run restriction.

In fine, the following order of Choleski factorization is deduced from our theoretical interpretation of the contemporary correlation matrix of the reduced form residuals of each country model. External variables are considered here as the most exogenous. For the domestic variables, two schemes have been selected, depending on the dominant exchange rate regime for the period of estimation. So, the order of the variables for Argentina from the most to the least exogenous will be: I_IPI, EMBI, A_EN, $A \_R, A \_C P I$ and $A \_I P I$. On the other hand, for Brazil and Uruguay, we choose the order I_IPI, EMBI, i_CPI, $i \_R, i \_E N$ and $i \_I P I$ (with $i=B, U$ ). The assumption of an exogenous EMBI is shared by a majority of economists - in spite of the weight of Mercosur economies in this index - even if domestic indicators (fiscal deficit, monetary instruments, payment deficit...) can have some influence on

the EMBI+. In 1999, J.P.Morgan releases a new index, the EMBIG (for "global”) embodying more countries (27) and more titles. In this last index, LAC decreased to $61.5 \%$.

${ }^{12}$ The domestic interest rate is the money market one: it is not exactly equivalent of the Federal Fund Rate... but it is the only one available for this sample.

13. All the tests are available upon request to the authors.

${ }^{14}$ Look at Allegret and Sand (2006).

${ }^{15}$ Leeper and Faust (1997) criticize the wide use of long run restrictions to study the sources of business cycles because of the weak reliability of structural inference for finite samples. In particular, "unless strong restrictions are applied, conventional inferences regarding impulse responses will be badly biased in all sample sizes”. 
country specific spreads ${ }^{16}$. As explained, the ordering can be different for domestic variables. The contemporary correlation matrix of the reduced form residuals for Argentina points out the strong correlation of Argentinean interest rates with other domestic variables: we interpret this outcome as the consequence of the Currency Board regime with a passive monetary policy (and an exogenous interest rate with respect to prices and output); obviously, prices had no influence on a strictly pegged exchange rate. So, we consider here the output (or more exactly its proxy, the $A \_I P I$ ) as the main adjustment variable in such way that in our model, it is the most endogenous.

In Brazil and Uruguay, we consider prices as the most exogenous domestic variable: these countries have a long tradition of price indexation (the succession of stabilization packages managed to break pessimistic forward expectations of the accelerating inflation times; but it could not eliminate completely backward rigidities ${ }^{17}$. So, the policies of both these economies continue to be mainly driven by price stability targeting, even if the intermediary exchange rate regime allows a soft peg. As for Argentina, the output can be consider as an adjustment variable, i.e. the most endogenous in both country models.

\section{The model}

We estimated a VARs model in log difference of the variables (except interest rates and the $E M B I$ ) for each country. The number of lags in each model has been selected using the common set of criteria and tests (available on the software Eviews 5 and RATS 6). However, it is well known that conventional VAR estimation frequently leads to an over-parametrization (because of the number of explanatory variables and lags). Moreover, the VARs are subject to strong colinearity amongst the lagged right side variables: so, the significance of parameters and more generally the robustness of tests are relatively limited. In short, over parametrized models have poor forecasting accuracy ${ }^{18}$. So, in the presence of contradictory results (given by the usual criteria), we followed the parsimony principle and accepted one lag for every country case.

For each country " $K$ ", the standard (reduced) form of our VAR with constant is the following :

\footnotetext{
${ }^{16}$ Fernández-Arias and Panizza (2001) ; González-Rozada and Levy-Yeyati (2005).

17 On these points, look at Sand-Zantman and Trotignon, 2002, for the Brazil, and Clavijo, Regules, and Bogliaccini, 2005, for Uruguay.

${ }^{18}$ We excluded a Bayesian approach (BVAR), a way to deal with a great number of parameters (here those of lagged variables), thanks to prior information: in our case, such a bet could have been more arbitrary and hazardous (Amisiano and Giannini (1997)).
} 
1) for Argentina:

\begin{tabular}{|c|c|c|c|c|c|c|}
\hline$\Delta \ln \_I \_I P I(t)$ & & $\left(C_{I_{-} I P I}\right)$ & $C_{(1,1)}$ & $C_{(1,6)}$ & $\left(\Delta \ln \_I \_I P I(t-1)\right.$ & $\left(e_{I_{-} I P I}\right.$ \\
\hline $\operatorname{EMBI}(t)$ & & $C_{\text {EMBI }}$ & & & $\operatorname{EMBI}(t-1)$ & $e_{E N B I}$ \\
\hline$\Delta \ln \_A_{-} E n(t)$ & - ver ( DITM ) + & $C_{E n}$ & $C_{(i, j)}$ & & $\Delta \ln \_A_{-} E n(t-1)$ & $e_{E n}$ \\
\hline$A \_R(t)$ & $=\operatorname{vec}\left(D \cup \| v_{A}\right)+$ & $C_{A_{-} R}$ & & & $A_{-} R(t-1)$ & $e_{A_{-} R}$ \\
\hline$\Delta \ln \_A \_C P I(t)$ & & $C_{A_{-} C P I}$ & & & $\Delta \ln \_A \_C P I(t-1)$ & $e_{A_{-} C P I}$ \\
\hline$\Delta \ln \_A \_I P I(t)$ & & $C_{A_{-} I P I}$ & $C_{(6,1)}$ & $C_{(6,6)}$ & $\Delta \ln \_A \_I P I(t-1)$ & $e_{\mathrm{A}_{-} I P I}$ \\
\hline
\end{tabular}

2) for Brazil :
$\left(\begin{array}{l}\Delta \ln \_I \_I P I(t) \\ E M B I(t) \\ \Delta \ln \_B \_C P I(t) \\ B \_R(t) \\ \ln \_B \_E n(t) \\ \Delta \ln \_B \_I P I(t)\end{array}\right)$
$=v e c\left(D U M_{B}\right) \times v e c(1+t)+\left(\begin{array}{l}C_{I_{-} I P I} \\ C_{\text {EMBI }} \\ C_{B_{-} E n} \\ C_{B_{-} R} \\ C_{B_{-} C P I} \\ C_{B_{-} I P I}\end{array}\right)+\left(\begin{array}{ll}C_{(1,1)} & \\ & C_{(i, j)} \\ & \\ C_{(6,1)} & \end{array}\right.$
$\left.C_{(1,6)}\right)\left(\begin{array}{l}\Delta \ln \_I \_I P I(t-1) \\ E M B I(t-1) \text { or } U S \\ \Delta \ln \_A \_E n(t-1) \\ A_{-} R(t-1) \\ \Delta \ln \_A \_C P I(t-1) \\ \left.C_{(6,6)}\right) \\ \Delta \ln \_A \_I P I(t-1)\end{array}\right)+\left(\begin{array}{l}e_{I_{-} I P I} \\ e_{E M B I} \\ e_{E n} \\ e_{A_{-} R} \\ e_{A_{-} C P I} \\ e_{A_{-} I P I}\end{array}\right)$

3) for Uruguay:
$\left(\begin{array}{l}\Delta \ln \_I \_I P I(t) \\ E M B I(t) \\ \Delta \ln \_U \_C P I(t) \\ U \_R(t) \\ \ln \_U \_E n(t) \\ \Delta \ln \_U \_I P I(t)\end{array}\right)=v e c\left(D U M_{U}+t\right)+\left(\begin{array}{l}C_{I P I} \\ C_{E M B I} \\ C_{E n} \\ C_{A_{-} R} \\ C_{A_{-} C P I} \\ C_{A_{-} I P I}\end{array}\right)+\left(\begin{array}{l}C_{(1,1)} \\ \\ \\ C_{(6,1)}\end{array}\right.$

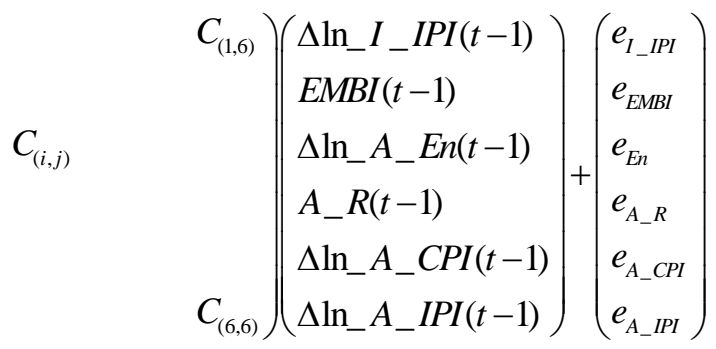

In order to account for specific country shocks during the period, and for the evidence of a deterministic trend affecting the set of variables- before the Real Plan for Brazil and in the whole period for Uruguay, we added the following dummies:

- $D U M_{A}$ for the first semester of 2002 in Argentina, to account for the Currency Board collapse;

- $D U M_{B}$ from 1990Q1 to 1994Q2 in Brazil, to account for the period of accelerating inflation, up to the Stabilization Real Plan,

- $\quad D U M_{U}$ for the whole year 2002 in Uruguay: after three years of economical and political mayhem from 1999 to 2002, the combination of political uncertainty - with the expectations of the left-wing party success in the national elections - and external shocks - due to Argentinean and Brazilian instability - has heavily affected the Uruguayan variables. 
One has to keep in mind that our three economies have adopted different exchange rate regimes. Furthermore, these have later evolved, following independent paths for the period. In short:

- from 1991 to 2001, Argentina was ruled by a currency board (hard peg) and then by an independent regime of floating;

- from 1991 to 1997, Brazil has adopted a crawling band regime (a kind of real exchange rate targeting) more or less "de jure" and more or less narrow, according to the context: in the following lines, we identify this regime as an intermediate exchange rate regime. After the strong currency crisis, in January 1999, Brazil implemented a flexible exchange rate regime combined with inflation targeting.

- From 1991 to 2001, Uruguay adopted an intermediate exchange rate regime based on crawling bands. In June 2002, the authorities decided to implement a floating regime.

Using this framework, we propose now to combine the impulse response functions (tracing out the time paths of the effects of "pure" shocks on the set of variables) and the forecast error variance decomposition (indicating the proportion of the movements in a sequence due to its "own" shocks versus to the other variables). These experiments aim at identifying what kind of shocks, real or nominal, drive economic fluctuations in the three countries. It allows us to make an assessment of the similarities in the reactions of macroeconomic variables to these shocks. By the way, we will get a first outline of the specific - versus common - economic consequences of shocks in terms of "spontaneous” adjustments and moreover in term of policy responses.

The results are presented in Appendix 2 and 3. When there is high correlation between some pairs of the reduced form residuals, the results can depend on the variable ordering in the Choleski factorization. So, we have tested the sensitivity of our results to alternative orders but we did not note significant changes in the conclusions for the more plausible permutations.

\section{Results}

Results analyzed hereafter refer to the most significant responses of domestic variables to shocks included in our VAR system.

\section{Responses of domestic variables to an external real shock: the I_IPI shock}

In the three countries, domestic industrial production increases after a shock on IPI of industrial countries. Conjuncture in industrial countries exerts an influence on business cycles in Mercosur countries. Variance decompositions (see Appendix 3) show that this influence is especially strong for Argentina: after 6 periods, I_IPI innovations explain between 13 and 16\% of the $A \_I P I$ variance. Brazil -as a relatively closed economy- and Uruguay -where the dependence on US conjuncture is more pronounced- do not exhibit such influence of the I_IPI. The responses of domestic interests rates 
differ according to the exchange rate regime. Thus, in Brazil, the shock on I_IPI induces a strong increase in interest rates during the first two quarters, followed by a smooth adjustment towards the initial equilibrium. On the other hand, Argentinean interest rates decreases after the shock. We interpret this asymmetric response of interest rates in the two main Mercosur countries as a consequence of the exchange rate regimes on inflation expectations. More precisely, the Argentinean currency board gives the economy a stronger nominal anchor. As a result, inflationary pressures in Argentina are less present than in Brazil.

In these two countries, I_IPI innovations explain more than $10 \%$ of the domestic interest rates variance. For Argentina, the influence is especially important with a persistence effect: the share explained by $I \_I P I$ increases with the number of periods.

\section{Responses of domestic variables to international financial shock}

Responses to shocks and variance decompositions allow us to draw some general lessons suggesting that Argentina is especially sensible to the $E M B I$ shock.

Two factors explain the specific vulnerability of Argentina to the pure international financial shock. On one hand, over the studied period, Argentina has been one of the main borrower in international capital markets. Until the end of the 1990s', Argentina benefited from very favorable conditions to borrow. So, capital inflows increased during this period. After 1999, its spread dramatically increased. Argentina suffered from a sudden-stop of capital inflows (Calvo, Izquiro, and Talvi (2003)) whose main consequence was a drop in domestic output. As a result, in comparison to the two other countries, the Argentinean economy appears especially sensible to EMBI fluctuations. On the other hand, the monetary policy constraints due to the currency board limit the ability of authorities to react in face of EMBI shocks, inducing strong and ample macroeconomic variability. From this point of view, the exchange rate regime exacerbated the sudden-stop problem. While in countries with floating exchange rates the domestic currency tends to depreciate after an increase in the EMBI, in hard peg countries such as Argentina, the impact of the shock is more pronounced on consumption prices and industrial production: prices and production decrease after the EMBI shock.

In the two countries with intermediate regimes, responses of domestic variables and their variance decompositions suggest that prices, production and interest rates are not significantly affected by the international financial shock. Brazilian and Uruguayan exchange rates are influenced by this shock. In the two countries, the domestic money depreciates after the shock. The exchange rate absorbs in part the negative impact of the international financial shock. This explains the weak responses of other domestic variables to this shock. We observe the opposite for Argentina. Thus our results exhibit a clear distinction between countries with soft pegs and countries with hard pegs.

\section{Responses of domestic variables to real domestic shock}

In the three countries, domestic IPI shocks do not lead to significant responses of other variables. Variance decompositions bring out the fact that no other domestic variable has its variance in part 
explained by IPI innovations. Over the studied period, the industrial production is an adjustment variable. This similarity across our three countries is explained by monetary policy constraints faced by domestic authorities either in the case of a hard peg (Argentina) or in the case of an economic policy based on the fight against inflation (Brazil and Uruguay).

\section{Responses of domestic variables to nominal domestic shocks}

We consider a shock on CPI (Consumption Price Index) as a nominal demand one. This shock allows us to discriminate between hard peg and soft peg countries. In addition, it appears that Brazil and Uruguay -the two economies with soft pegs- react differently to this shock.

Argentina exhibits a rapid adjustment without major fluctuations of other domestic variables. Variance decompositions of domestic variables show that A_CPI innovations explain only its own variance, whatever the considered period. This lack of reaction is a consequence of the effect of the currency board on the inflation anchor.

In countries with soft pegs, inflation expectations are imperfectly anchored. So, in Brazil and Uruguay, shocks on prices induce higher fluctuations than in Argentina. In Brazil, the shock is short lived, less than two quarters, while it is strong and persistent in Uruguay suggesting the existence of nominal rigidities in the later. In both countries, the shock is followed by a recession (a decline in IPI): higher prices go with pessimistic expectations. Interest rate responses are strong in the short term, and the adjustment is slow especially in Uruguay. This path is explained by a weaker credibility of monetary policy. Monetary authorities are constrained to react quickly in order to prevent the development of indexation mechanisms. On nominal exchange rates, we have a significant depreciation over different horizons: a very short term response in Brazil (less than one quarter) and a longer impact for Uruguay (more than four quarters). In both countries price innovations explain a significant share of the exchange rate variance. These links between prices and exchange rates could mean that these two countries had a real exchange rate target in the 1990s'. As a small open economy, this target has been especially important in Uruguay.

\section{Responses of domestic variables to domestic monetary policy shocks}

The innovations on nominal interest rate are monetary policy shocks. The adjustments after an interest rates shock differ according to the exchange rate regime: very fast in Argentina (less than one quarter); four quarters (Brazil) or more (Uruguay) for intermediate exchange rate regime countries. Thus the resilience of the monetary policy shock seems higher in this second group of countries. Two opposing interpretations of this different path are conceivable: first, an insufficient credibility of monetary policy in economies with soft pegs; second, a more reactive monetary policy as a result of the less binding exchange rate regime. The analysis of the responses of other domestic variables leads us to consider that the first explanation is the most relevant: even in countries with intermediate regimes, monetary policy reacts little to non-inflationary shocks revealing a "fear of floating" behavior (Calvo and Reinhart (2002)). 
The responses of consumption prices contrast in the three countries. No price puzzle appears in Argentina and Uruguay: prices decrease after the interest rate shock. On the other hand, not only Brazilian prices increase as a result of the shock, but the return towards equilibrium appears after five quarters. Prices movements can be interpreted as a Cavallo-Patman effect where higher interest rates increase production costs via the financing needs of working capital, leading to inflationary pressures (Taylor (1981)). The variance of $B \_C P I$ is strongly explained by interest rate innovations: $31 \%$ in period 2; 38-39\% after period 6. The increase in the interest rate in Brazil can be interpreted as the result of a credibility loss in a context of fear of inflation. From this point of view, the interest rate is overall an indicator of inflationary pressures neither than a response to them (Favero and Giavazzi (2002)).

Nominal exchange rates exhibit weak responses in Argentina and Uruguay. On the contrary, the reaction is strong and long-lasting (approximately four quarters) for Brazil. The nominal exchange rate follows a traditional overreaction mechanism: appreciation at the impact, then strong depreciation. We interpret the evolution as an insufficient credibility of the monetary authorities. According to variance decompositions of nominal exchange rates, innovations on interest rate do not explain a significant part of their variance, except in Brazil.

\section{Responses of domestic variables to nominal exchange rate shocks}

The response of production in Brazil is weak. This result is consistent with the main characteristics of the Brazilian economy: low openness and dollarization degrees. In addition, exchange rate innovations do not explain the variance of other domestic variables. In Argentina and Uruguay, IPI decreases after the shock, but with a lagged effect in the latter country. Indeed, dollarization in these two economies implies that domestic currency depreciation produces a negative balance sheet effect. The dollarization of external debt in Argentina explains the stronger response of $I P I^{19}$. Exchange rate innovations explain $13 \%$ of the $A \_I P I$ variance contemporaneously and $10-11 \%$ after six periods.

Responses of prices suggest that pass-through effects are either absent (Argentina and Uruguay) or short-lived (Brazil). These results reinforce other studies which stressed the decrease of the exchange rate-domestic prices transmission in LAC since the 1990s’ (Larrain and Velasco (2001)).

Interest rate responses are weak and insignificant (see variance decompositions) in Brazil and Uruguay. As expected under currency board arrangement, Argentinean interest rates react strongly at the impact of the shock. They increase in the two first quarters.

\section{The main implication of our results from our semi-structural VAR is the following:}

\footnotetext{
19. Using the classification proposed by Reinhart, Rogoff and Savastano (2003), Argentina and Brazil belong to Type I dollarization -in which domestic and external liability dollarization co-exist- while Uruguay is a dollarized economy of Type II where dollarization is predominantly of a domestic nature. The degree of dollarization is different between these countries: high in Argentina (index 20 on a scale that goes from 0 to 30) and Uruguay (21), but moderate in Brazil (7).
} 
Countries with intermediate exchange rate regimes seem more sensitive to nominal shocks while our hard peg country (Argentina) strongly responds to external financial shock (EMBI shock). In other words, the diversity of the exchange rate regimes among Mercosur countries explain the fact that these countries are vulnerable to different shocks and that the domestic dynamics are different after the shocks. Second, our three countries have a similar characteristic: industrial production exerts a weak influence on other variables.

From this point of view, Argentina, Brazil and Uruguay do not constitute an optimal currency area. Our space-state model will confirm this outcome.

\section{Identification of common and country specific components of structural shocks using a state-space model}

The main purpose of structural VAR estimation is to get non-recursive orthogonalization of the error terms for impulse response analysis and variance decompositions of forecast errors. Whatever the identification restrictions (short or long run), and their theoretical (or "a-theoretical") foundations (choice of an "ad-hoc" scheme of identification, or decomposition " à la Blanchard et Quah" contrasting demand and supply shocks on the basis of long run neutrality on the supply side), these experiments don't allow the distinction between common and specific components of fluctuations and shocks. However, this distinction, and overall the weight of common component, are the fundamental criteria of judgment in the choice of economic and monetary integration. Following the OCA theory, a too light weight of common component implies significant adjustment of exchange rates in the case of strong shocks. Such adjustments are difficult to endure in a simple free trade area. Moreover, it becomes impossible in the case of a common monetary zone. In short, any integration process implies symmetry, i.e. a large common component.

In order to assess the share of the common and idiosyncratic components in the variability of the structural shocks (policy shocks included), we propose a breakdown in two unobservable stochastic components using the Kalman filter (Harvey (1989), Kim and Nelson (1999)). The same method has been used by Bosco N'Goma (2000) for members of CFA Zone, by Chamie, Desserres, and Lalonde (1994) for a comparison between Europe and the USA, or by Lalonde and St-Amand (1993) for ALENA. We report here a sum up of the explanations proposed by this set of papers.

\section{Methodology}

The state-space models distinguish observed variables (the "signal” or "observation") and unobserved variables ("state" variables). They are composed of two sets of equations:

One or several "signal " (or "measurement”) equations relating the observable variables to the unobservable states ; 
One or several "state" (or "transition") equations describing how the vector of "states" evolves over time.

In this part, we aim at breaking down shocks affecting jointly the three members of Mercosur - or any pair of them - into two unobservable components: a common component for the three countries - or at least for two of them- and an idiosyncratic component, specific for each country. We note :

the three members by $i=A, B$ and $U$ respectively for Argentina, Brazil and Uruguay ;

$\varepsilon_{i_{-} j, t}$ the real or nominal shocks, for the period « $t$ », with $j=I P I, C P I, E n, R$;

$\left\{n_{C_{-}, t}\right\}$ the common components ;

$\left\{n_{i_{-} j, t}\right\}$ the idiosyncratic components ;

$\alpha_{i_{-} j}$ and $\left(1-\alpha_{i_{-} j}\right)$ the respective weight of common and idiosyncratic components in each shock $\varepsilon_{i_{-}, t}$;

The decomposition consists of the estimation of the parameters $\alpha_{i_{-} j}$ and the time series $\left\{n_{C_{-} j, t}\right\}$ and $\left\{n_{i_{-}, t, t}\right\}$.

In our state-space model, the following equations:

$$
\left(\begin{array}{l}
\varepsilon_{A_{-} j, t} \\
\varepsilon_{B_{-} j, t} \\
\varepsilon_{U_{-} j, t}
\end{array}\right)=\left[\begin{array}{llll}
\alpha_{A_{-} j} & \left(1-\alpha_{A_{-} j}\right) & 0 & 0 \\
\alpha_{B_{-} j} & 0 & \left(1-\alpha_{B_{-} j}\right) & 0 \\
\alpha_{U_{-} j} & 0 & 0 & \left(1-\alpha_{U_{-} j}\right)
\end{array}\right]\left[\begin{array}{l}
n_{C_{-} I P I, t} \\
n_{A_{-} I P I, t} \\
n_{B_{-} I P I, t} \\
n_{U_{-} I P I, t}
\end{array}\right]
$$

constitute the measurement (or transition) system, with the structural innovations - stemming from the decomposition of our reduced form VAR residuals - as endogenous variables.

To estimate the parameters $\alpha_{i_{-} j}$ and the series $n_{C_{-}, t}$ and $n_{i_{-}, t,}$, we need a set of transition equations, specifying the dynamics of the unobservable components. For identification purposes, we assume that common and specific components are uncorrelated. In a large number of software packages - and in particular Eviews 5 and Rats 6, used here - the identifying restrictions assume normalized structural innovations $\varepsilon_{i_{-} j, t}$, with unit variance. This normalization facilitates the comparison of structural shocks, stemming from our different country VARs estimated separately! We will also assume unit variance for the unobservable components. While determining the stochastic components path through the definition of their distributions, this assumption defines the transition equations. So, we can write as "state” system: 


$$
\begin{aligned}
\Omega & =\left[\begin{array}{cccc}
\operatorname{Var}\left(n_{C_{-} j, t}\right) & 0 & 0 & 0 \\
0 & \operatorname{Var}\left(n_{A_{-} j, t}\right) & 0 & 0 \\
0 & 0 & \operatorname{Var}\left(n_{B_{-} j, t}\right) & 0 \\
0 & 0 & 0 & \operatorname{Var}\left(n_{U_{-} j, t}\right)
\end{array}\right] \\
& \left\{\begin{array}{l}
\operatorname{Var}\left(n_{C_{-} j, t}\right)=1 \\
\operatorname{Var}\left(n_{A_{-}, t}\right)=1 \\
\operatorname{Var}\left(n_{B_{-} j, t}\right)=1 \\
\operatorname{Var}\left(n_{U_{-} j, t}\right)=1
\end{array}\right.
\end{aligned}
$$

Finally, we must choose a reference country shock to which the other shocks will be compared: we will choose Argentina when Argentina is present (and Brazil in the other cases) and start estimation initializing $\alpha_{i_{-} j}=1$. The Kalman filter algorithm will be used to decompose the structural shock and idiosyncratic and (if they exist) common components.

\section{Results}

The main result is that we can never observe any significant common component for the three countries $^{20}$ ! But for some variables, the estimation showed the presence of common components for pairs of Mercosur countries.

So, in the case of CPI, the inflation path has a weak but significant common component of $9 \%$ for Argentina and Brazil

Table 1 Decomposition of inflation innovations for Argentina and Brazil

\begin{tabular}{lllll} 
CPI_MB_AB & Coefficient & Std. Error & z-Statistic & Prob. \\
\hline \hline C(1) & 0.992180 & 0.068671 & 14.44830 & 0.0000 \\
C(2) & 0.088781 & 0.036808 & 2.412014 & 0.0159
\end{tabular}

We can find a common component nearly equivalent in the case of the nominal exchange rate for Argentina and Brazil. Considering the differences in both the exchange rate regimes during the better part of the period, it could seem paradoxical. But it accounts for the common volatility of the years 2001-2002 triggered by the Argentinean crisis and worsened by the political uncertainty in Brazil.

\footnotetext{
${ }^{20}$ The foreign variables, the IPI for industrialized countries and either the EMBI, are endogenous in each one of our country models: so we can deduce orthogonal shocks for both these variables. Obviously, looking for a common component in these case doesn't present any theoretical interest. But allowed us to check the efficiency of the Kalman Filter: we found indeed the predicted result of a strong significant common component in every case.
} 
Table 2 Decomposition of innovations for nominal exchange rates in the case of Argentina and Brazil

\begin{tabular}{lllll} 
En_MB_AB & Coefficient & Std. Error & z-Statistic & Prob. \\
\hline \hline C(1) & 0.992144 & 0.042701 & 23.23442 & 0.0000 \\
C(2) & 0.088986 & 0.037234 & 2.389951 & 0.0169
\end{tabular}

At last, we find also a weak - but significant - common component of $15 \%$ for both the main economies of Mercosur.

Table 3 Decomposition of innovations for domestic industrial growth rate in the case of Argentina and Brazil

\begin{tabular}{lllll} 
IPI_MB_AB & Coefficient & Std. Error & z-Statistic & Prob. \\
\hline \hline $\mathrm{C}(1)$ & 0.979247 & 0.049178 & 19.91226 & 0.0000 \\
$\mathrm{C}(2)$ & 0.145616 & 0.072461 & 2.009569 & 0.0445
\end{tabular}

Curiously, Uruguay doesn't exhibit these features: but the extent of idiosyncratic domestic volatility during the period displayed by the primary data (see Allegret and Sand-Zantman (2006)) probably conceals a large part of the foreign perturbations spillover.

However, the outcomes are slightly different for nominal interest rates: as shown in the following table, Brazil and Uruguay exhibit a small common component (about 8.5\%).

Table 4 Decomposition of innovations for domestic interest rate in the case of Brazil and Uruguay

\begin{tabular}{lllll} 
R_MB_BU & Coefficient & Std. Error & z-Statistic & Prob. \\
\hline \hline C(2) & 0.993101 & 0.050234 & 19.76943 & 0.0000 \\
C(3) & 0.083350 & 0.041380 & 2.014267 & 0.0440
\end{tabular}

In brief, it is difficult to exhibit an unambiguous and significant macroeconomic convergence of the three Mercosur partners, either in terms of weight or in terms of statistical significance. In particular, the exceptional macroeconomic volatility of Uruguay during the period conceals any foreign influence. Argentina and Brazil, which have known a significant trend of trade integration before the Brazilian crisis of 1998-1999, and shared common waves of speculative attacks after the collapse of the Argentinean currency board seem to exhibit symptoms of common shocks.

But finally, in spite of the evidence of common shocks linked to world conjuncture or to speculative behavior on the international financial market, the policy mix of the Mercosur members remains strongly specific. 


\section{Conclusion}

Our results converge to indicate that the Mercosur countries are not predisposed to form a monetary union either between them, or with the United States. First, the SSVAR proves the weak coordination of economic policies between these countries. In particular, identical nominal shocks involve different adjustment paths. This low level of synchronization and policy coordination is confirmed by the "state-space" models: the latter displayed the weak common component of the various shocks involved in the experiments. Second, including a typical common international financial shock - here the EMBI - suggests one more time idiosyncratic responses: obviously, the variety of exchange rate regimes and policies in the area during this period did not ease convergence and coordination!

In short, our results stay in line with the whole literature on the Latin American integration process. Furthermore, it confirms the theoretical analyses relative to the place of exchange rate regimes adjustments in the face of macroeconomic shocks.

It must be stressed that these results stem from SSVAR studies including more variables than the majority of papers published on the subject. However, these analyses must be deepened in some privileged directions. First, accounting for the EMBI allowed us to provide a better assessment of the world financial shocks impact on the feasibility of monetary unions; but domestic consequences of structural breaks - linked to these shocks - continue to be imperfectly grasped: in particular, we did not embody explicitly implications of the "sudden stop" hitting Latin American economies during these times. A hint would be to include some of the more relevant variables allowing to account for these facts: trade balance, current accounts, or international reserves could be used to test the impact of "sudden stop" of capital inflows on trade balance and output. Second, our set of variables did not exhibit any cointegrating vector: it is probably due to the presence of structural breaks. A next step will be to deal with this issue in order to build a VECM (Vector Error Correction Model) able to embody short and long run dynamics, allowing us to focus on respective speeds of adjustment: indeed, very different speeds of adjustment could prejudice any project of monetary integration (except obviously for the endogenous OCA perspective).

\section{References}

Ahmed S. (2003), "Sources of economic fluctuations in Latin America and implications for choice of exchange rate regimes”, Journal of Development Economics, vol.72, n¹, pp.181-202.

Alesina A. and Barro R.J. (2002), “Currency unions”, The Quarterly Journal of Economics, vol.117, n², pp.409-436.

Alesina A., Barro R.J. and Tenreyro S. (2003), “Optimal currency areas”, in M. Gertler and K. Rogoff (eds), NBER Macroeconomic Annual 2002, The MIT Press, Cambridge, Mass.

Allegret J.P. and Sand-Zantman A. (2006), "Disentangling business cycles and macroeconomic policy in Mercosur: a VAR and unobserved components model approaches", New developments in 
macroeconomic modelling and growth dynamics, September 7-9, Algrave University, Portugal ; Working Paper OFCE, n²006-15.

Allen P.G. and Fildes R. (2004), "Levels, differences, and ECM: principal for improved economic forecasting”, Working Paper n 2004-2, University of Massachusetts Amherst.

Amisiano G. and Giannini C. (1997), Topics in structural VAR Econometrics, $2^{\text {nd }}$ Ed., SpringerVerlag.

Berg A., Borensztein E. and Mauro P. (2002), "An evaluation of monetary regime options for Latin America”, The North American Journal of Economics and Finance, vol.13, 2, pp.213-235.

Blanchard O. and Quah D. (1989), "The dynamic effects of aggregate demand and supply disturbances », American Economic Review, vol.79, n4, p.655-673.

Bruner F.A and Rigobon R. (2004), "Why are capital flows so much volatile in emerging than in developed countries?”, $8^{\text {th }}$ Annual Conference, Central Bank of Chile, External financial vulnerability and prevention policies, August.

Bosco N’Goma J.M. (2000), “Analyse des chocs d'offre et de demande dans la zone CFA: une méthode structurelle d’autorégression vectorielle”, Cahier n¹3-2000, CRDE, Université de Montréal.

Calvo G.A. (2005), “Crises in emerging market economies: a global perspective”, NBER Working Paper Series, n¹1305, April.

Calvo G.A., Izquiro I., and Talvi E. (2003), "Sudden stops, the real exchange rate, and fiscal sustainability: Argentina's lessons”, NBER Working Paper Series, n9828, July.

Calvo G.A., Leiderman L. and Reinhart C.M. (1993), "Capital inflows and real exchange rate appreciation in Latin America, the role of external factors", IMF Staff Papers, vol.40, n¹, pp.108-151.

Calvo G. and Reinhart C.M. (2002), "Fear of floating”, The Quarterly Journal of Economics, vol.117, $\mathrm{n}^{\circ} 2$, pp.379-408.

Canova F. (1995), "Vector autoregressive models: specification, estimation, inference, and forecasting", in The Handbook of Applied Econometrics: Macroeconomics, H. Pesaran and M. Wickens (eds), Basil Blackwell,

Canova F. (2005), "The transmission of US shocks to Latin America”, Journal of Applied Econometrics, vol.20, pp.229-251.

Carrera J.E., Féliz M, Panigo D. and Saavedra M. (2002), "How does dollarization affect real volatility? A general methodology for Latin America”, Mimeo, April.

Chamie N., De Serres Alain and Lalonde R. (1994), "Optimum currency areas and shock asymmetry: a comparison of Europe and the United States”, Working Paper n94-1, Bakn of Canada.

Clavijo P.I., Regules J.M. and Bogliaccini J. (2005) “Terminios de Intercambio y salario real”, Mimeo UDELAR, XX jornadas anuales de Economia, Banco Central del Uruguay.

Cunningham, A. (1999), "Emerging economy spread indices and financial stability”, Financial Stability Review, November.

Doan T.A. (2004), Rats Version 6, User’s Guide, Estima.

Eichengreen B. (1998), «Does Mercosur need a single currency ? », NBER Working Paper Series, n6821, décembre.

Eichengreen B. and Taylor A.M. (2004), "The monetary consequences of a free trade area of the Americas”, in A. Estevadeordal, D. Rodrik, A.M. Taylor and A. Velasco (eds), Integrating the americas : FTAA and beyond, Harvard University Press.

Enders, W., 2004, Applied Econometric Time Series, 2nd ed. John Wiley and Sons. 
Fanelli J. and González-Rozada M. (2003), "Business cycle and macroeconomic policy coordination in MERCOSUR”, Centro de Investigación en Finanzas, Université Torcuato Di Tella, document de travail $n^{\circ} 16 / 2003$, September.

Faust J. and Leeper E.M. (1997) "When do long-run identifying restriction give reliable results?", Journal of Business \& Economic Statistics, vol.15, n³, pp.345-353.

Favero C. (2001), Applied macroeconometrics, Oxford University Press.

Favero C.A. and Giavazzi F. (2002), “Why are Brazil’s interest rates so high?”, Working Paper n²24, July, IGIER-Università Bocconi, Milan.

Fernandez-Arias E. (1996), “The new wave of private capital inflows: push or pull?”, Journal of Development Economics, vol.48, pp.389-418.

Hallwood P., Marsh I.W. and Scheibe J. (2004), “An assessment of the case for monetary union or official dollarization in Argentina, Brazil, Chile, Uruguay and Venezuela”, University of Connecticut, Department of Economics Working Paper Series, n²004-13, July.

Harvey A.C. (1990), Forecasting. Structural times series models and the Kalman filter, Cambridge University Press.

Karras G. (2003), “The prospect of dollarization: are the Americas an optimum currency area?”, in C. Tsoukis, G.M. Agiomirgianakis and T. Biswas (eds.) Aspects of Globalisation : Macroeconomic and Capital Market Linkages in the Integrated World Economy, Kluwer Academic Publishers, Dordrecht, pp.183-199.

Kim. C.J. and Nelson C.R. (1999), State Space Models with regime switching, The MIT Press.

Lalonde R. and St-Amant P. (1993), “Zones monétaires optimales: cas du Mexique et des Etats-Unis”, Working Paper n93-12, Bank of Canada.

Larrain F. B. and Tavares J. (2003), "Regional currencies versus dollarization: options for Asia and the Americas”, Policy Reform, vol.6, n²1, pp.35-49.

Larrain F.B. and Velasco A. (2001), "Exchange-rate policy in emerging-market economies: the case for floating”, Essays in International Economics, International Finance Section, Princeton, $n^{\circ} 224$.

Levy-Yeyati E.L. and Sturzenegger F. (2000), “EMU a blueprint for Mercosur?”, Cuadernos de Economia, vol.37, n¹10, pp.63-99.

Loayza N., Lopez H. and Ubide A. (1999), "Sectorial macroeconomic interdependencies: evidence from Latin America, East Asia and Europe”, IMF Working Paper, WP/99/11, January.

Lütkepohl H. and Krätzig M. (eds), (2004), Applied time series econometrics, Cambridge University Press.

Perron P. (1997), "Further evidence on breaking trend functions in macroeconomic variables”, Journal of Econometrics, vol. 80, n², pp.355-385.

Rand J. and Tarp F. (2002), "Business cycles in developing countries: are they different?”, World Development, vol.30, n²12, pp.2071-2088.

Rose A.K. and Engel C. (2002), “Currency unions and international integration”, Journal of Money Credit and Banking, vol.34, n²2, Nomvember, p. 1067-1089.

Sand-Zantman A. and Trotignon J. (2002) "Brésil: l'Héritage de Fernando Henrique Cardoso”, Revue de l'OFCE, n83, Octobre, p.291-324.

Sims C.A. (1980), “Macroeconomics and reality”, Econometrica, vol. 48, n¹, pp.1-48.

Taylor L. (1991), Income distribution, inflation and growth: lectures on structuralist macroeconomic theory, Cambridge: MIT Press.

Uribe M. and Yue V.Z. (2006), “Country spreads and emerging countries: who drives whom?”, Journal of International Economics, 69, pp.6-36. 


\section{Appendix 1 Residuals correlation matrix of reduced forms of SSVAR estimations.}

Argentina :

\begin{tabular}{|c|c|c|c|c|c|c|}
\hline & DLI_IPI & EMBI & DLA_IPI & DLA_CPI & A_R & DLA_EN \\
\hline DLI_IPI & 1.000000 & & & & & \\
\hline EMBI & -0.011770 & 1.000000 & & & & \\
\hline DLA_IPI & 0.162367 & -0.214967 & 1.000000 & & & \\
\hline DLA_CPI & 0.073598 & -0.070295 & 0.275767 & 1.000000 & & \\
\hline A_R & -0.258758 & 0.263431 & -0.334864 & -0.292683 & 1.000000 & \\
\hline DLA_EN & 0.139414 & 0.102633 & -0.357663 & -0.253702 & 0.061690 & 1.000000 \\
\hline
\end{tabular}

Brazil

$\begin{array}{lcc} & \text { DLI_IPI } & \text { EMBI } \\ \text { DLI_IPI } & 1.000000 & \\ \text { EMBI } & -0.124227 & 1.000000 \\ \text { DLB_IPI } & 0.211992 & -0.117485 \\ \text { DLB_CPI } & 0.008888 & 0.065573 \\ \text { B_R } & 0.175577 & 0.12529 \\ \text { DLB_EN } & 0.014061 & 0.36180\end{array}$

DLB_IPI

B_R

DLB_EN

Uruguay

\begin{tabular}{|c|c|c|c|c|c|c|}
\hline & DLI_IPI & EMBI & DLU_IPI & DLU_CPI & U_R & DLU_EN \\
\hline DLI_IPI & 1.000000 & & & & & \\
\hline EMBI & -0.152621 & 1.000000 & & & & \\
\hline DLU_IPI & 0.078686 & -0.068776 & 1.000000 & & & \\
\hline DLU_CPI & -0.127314 & 0.079218 & -0.134949 & 1.000000 & & \\
\hline U_R & 0.068115 & 0.095316 & -0.075089 & 0.551850 & 1.000000 & \\
\hline DLU_EN & -0.139600 & 0.110233 & -0.049260 & 0.750403 & 0.560811 & 1.000000 \\
\hline
\end{tabular}

Appendix 2 Responses to Cholesky One SD (Innovations \pm 2 SE)

\section{Argentina}

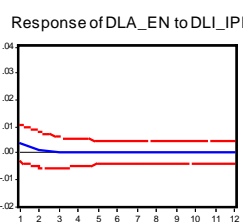

Response of A_Rto DLI IPI

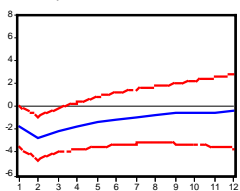

Response of DLA_CPI to DLI IPI

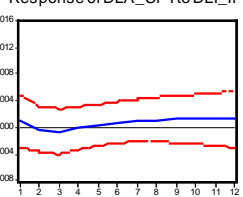

Response of DLA_IPI to DLIIPI

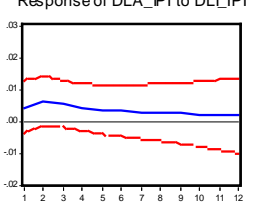

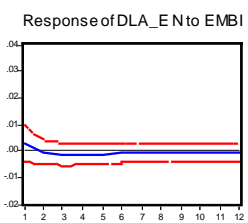

Response of A_R to EMBI

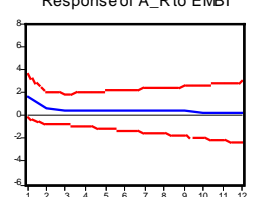

Response of DLA_CPI to EMBI

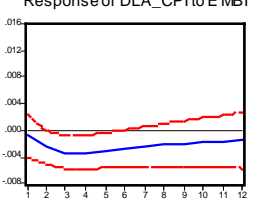

Response of DLA_IPI to EMBI

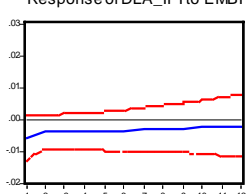

Response of DLA_EN to DLA_EN

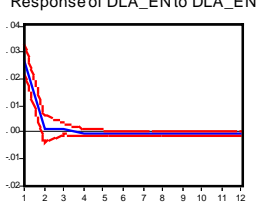

Response of A_R to DLA_EN

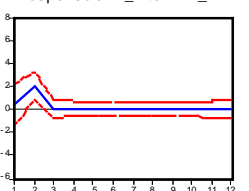

Response ofDLA_CPI to DLA_EN

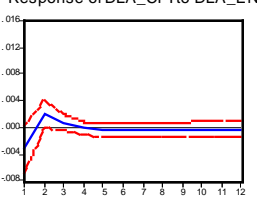

Response ofD LA_IPI to DLA_EN

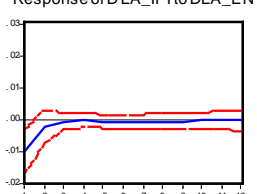

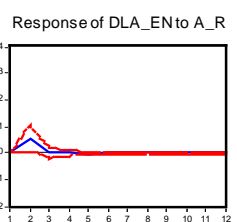

Response of $A \_R$ to $A \_R$

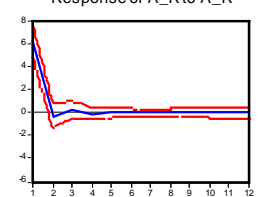

Response of DLA_CPIto A_R

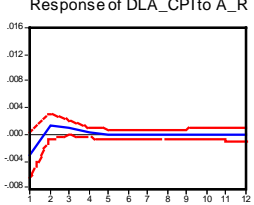

Response of DLA_IPI to A_R

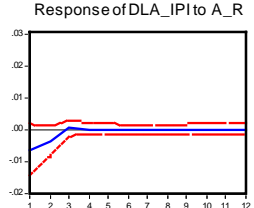

Response of DLA_EN to DLA_CP

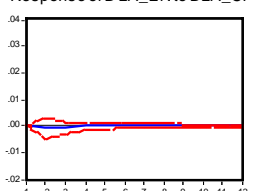

Response of A R to DLA CPI

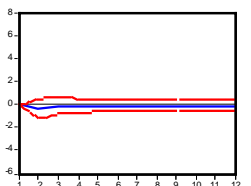

Response of DLA_CPItoDLA_CPI

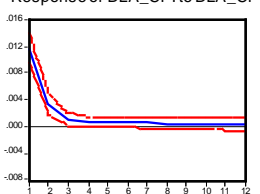

Response ofDLA_IPIto DLA_CPI

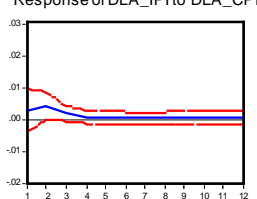

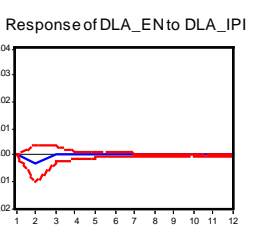

Response of A_R to DLA IPI

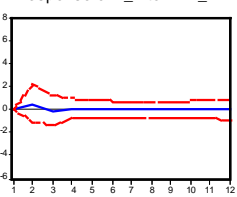

Response ofDLA_CPItoDLA_IPI

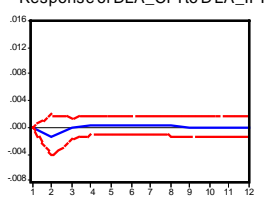

Response of DLA_IPI to DLA_IPI

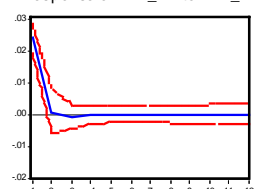




\section{Brazil}
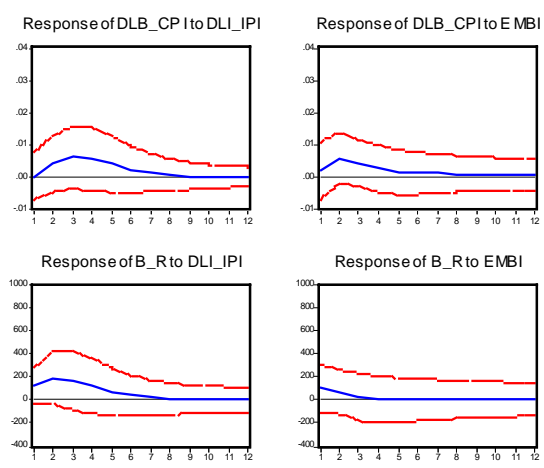

Response of DLB_EN to DLI_IPI

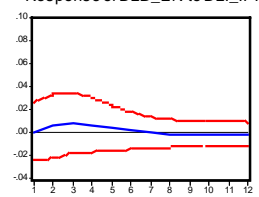

Response of DLB_PPI to DLIIPP
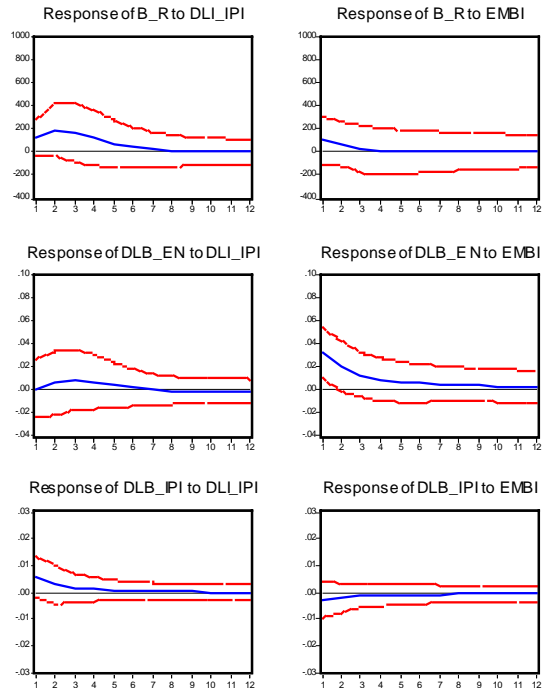

Response ofDLB_EN to EMB!

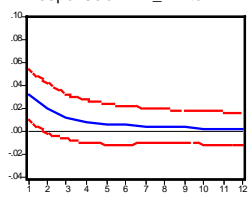

Response ofDLB_IPI to EMBI

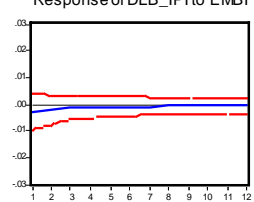

Response of DLB_CPI to B_R
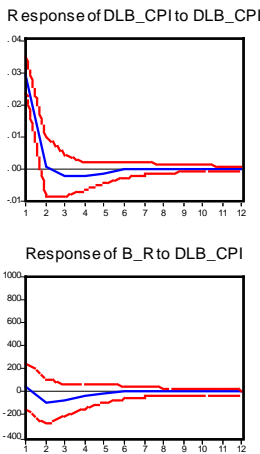

Response of DLB_EN to DLB_CPI

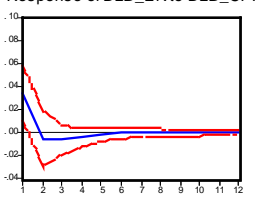

Response of DLB_IPIto DLB_CPI

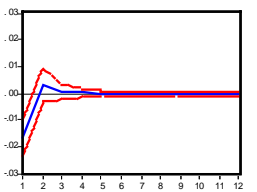

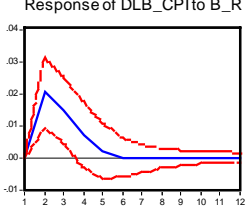

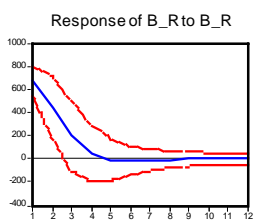

Response of DLB_EN to B_R

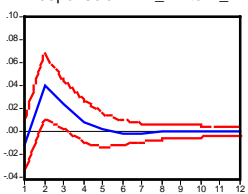

Response of DLB_IPI to B_R

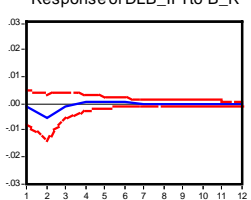

Response of DLB_CPI to DLB_EN

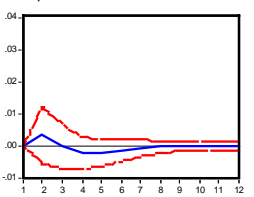

Response of $B$ R to DLB EN

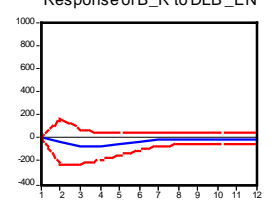

Response of DLB_ENtoDLB_EN

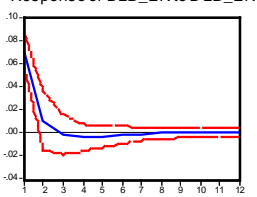

Response of DLB_IPI to DLB_EN

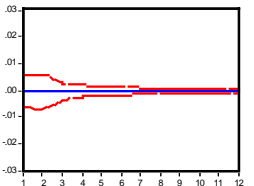

Response of DLB_CPItoDLB_IPI

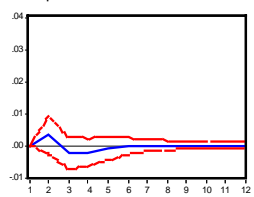

Response ofB_R to DLB_IPI

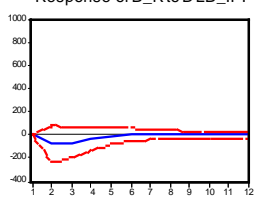

Response of DLB_ENto DLB_IPI

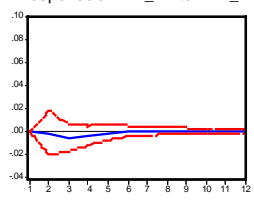

Response of DLB_IPI to DLB_IP

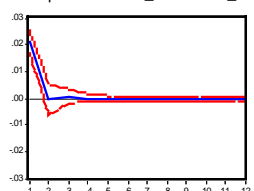

\section{Uruguay}
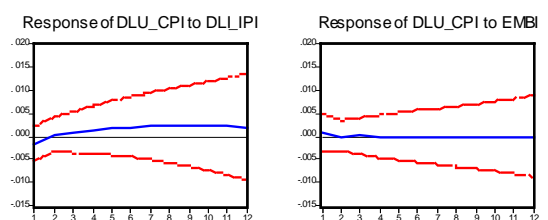

Response of U_R to DLI_IPI

Response of $U \_R$ to EMB
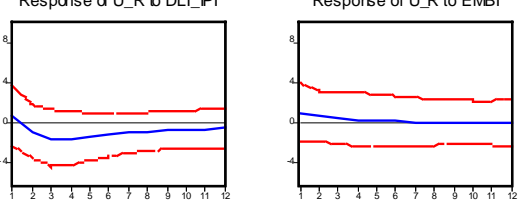

Response of DLU_ENto DLI IP

Response of DLU EN to EMB!
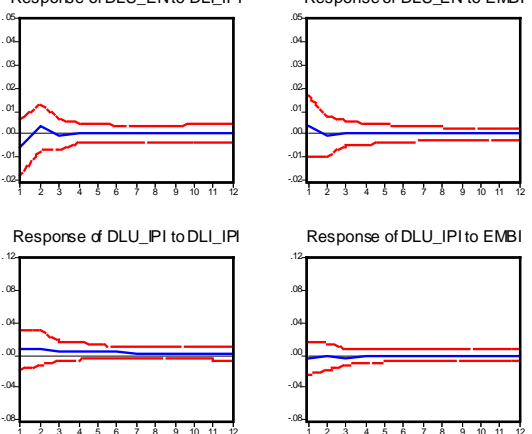
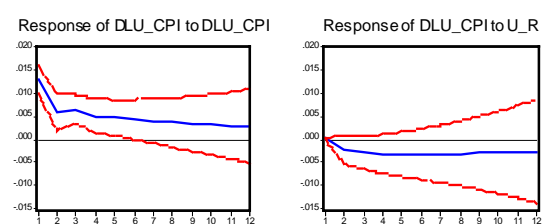

Response of U_R to DLU_CPI

Response of U_Rto U_R
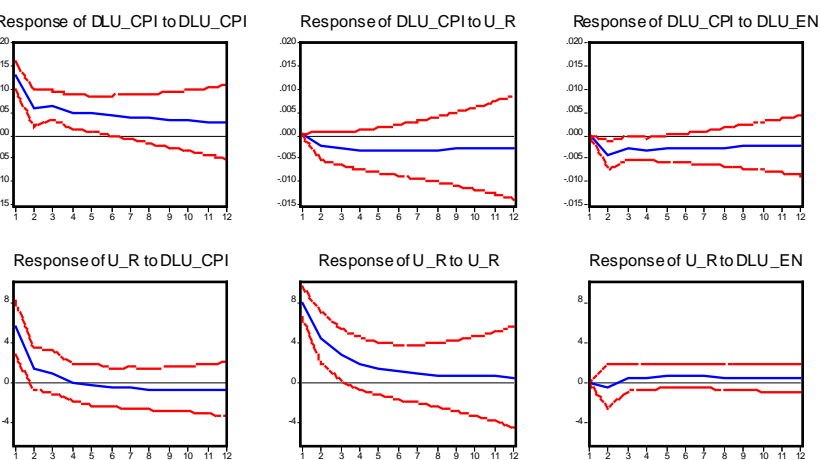

Response of U R to DLU EN

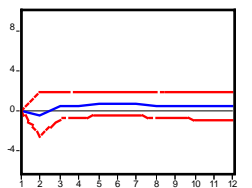

Response of DLU_ENto U R

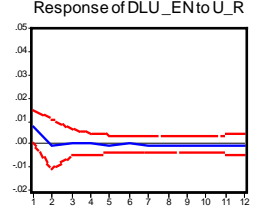

Response of DLU IPI to U R

Response of DLU_IPI to DLU CPI
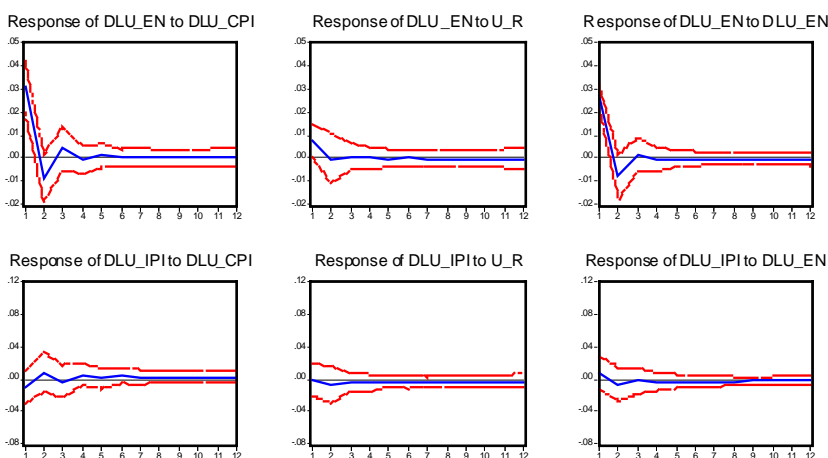

Response of DLU IPI to DLU EN

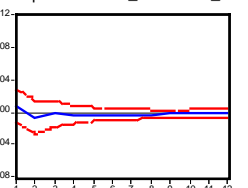

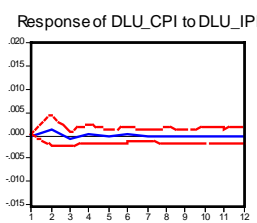

Response of U R to DLU IPI

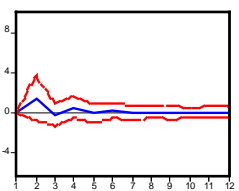

Response of DLU_EN to DLU_IPI

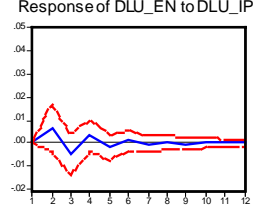

Response of DLU_IPI to DLU_IPI

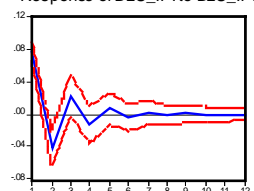


Appendix 3 Variance Decompositions, in \%

Argentina

A_EN Variance decomposition

\begin{tabular}{|c|c|c|c|c|c|c|}
\hline & IPI & EMBI & A_EN & A_R & A_CPI & A_IPI \\
\hline 1 & 2 & 1 & 97 & 0 & 0 & 0 \\
\hline 6 & 2 & 2 & 91 & 4 & 0 & 1 \\
\hline 12 & 2 & 2 & 91 & 4 & 0 & 1 \\
\hline
\end{tabular}

A_R Variance decomposition

\begin{tabular}{|c|c|c|c|c|c|c|}
\hline & IPI & EMBI & A_EN & A_R & A_CPI & A_IPI \\
\hline 1 & 7 & 7 & 1 & 86 & 0 & 0 \\
\hline 6 & 29 & 7 & 7 & 57 & 0 & 1 \\
\hline 12 & 31 & 8 & 7 & 54 & 0 & 1 \\
\hline
\end{tabular}

A_CPI Variance decomposition

\begin{tabular}{|c|c|c|c|c|c|c|}
\hline & IPI & EMBI & A_EN & A_R & A_CPI & A_IPI \\
\hline 1 & 1 & 0 & 7 & 7 & 86 & 0 \\
\hline 6 & 1 & 20 & 7 & 6 & 65 & 1 \\
\hline 12 & 4 & 27 & 6 & 5 & 58 & 1 \\
\hline
\end{tabular}

A_IPI Variance decomposition

\begin{tabular}{|c|c|c|c|c|c|c|}
\hline & IPI & EMBI & A_EN & A_R & A_CPI & A_IPI \\
\hline 1 & 3 & 5 & 13 & 5 & 1 & 73 \\
\hline 6 & 13 & 11 & 11 & 5 & 3 & 57 \\
\hline 12 & 16 & 14 & 10 & 5 & 3 & 53 \\
\hline
\end{tabular}

\section{Uruguay}

U_CPI Variance decomposition

\begin{tabular}{|c|c|c|c|c|c|c|}
\hline & I_IPI & EMBI & U_CPI & U_R & U_EN & U_IPI \\
\hline 1 & 2 & 0 & 98 & 0 & 0 & 0 \\
\hline 6 & 3 & 0 & 73 & 11 & 12 & 1 \\
\hline 12 & 7 & 0 & 62 & 16 & 15 & 0 \\
\hline
\end{tabular}

U_R Variance decomposition

\begin{tabular}{|c|c|c|c|c|c|c|}
\hline & I_IPI & EMBI & U_CPI & U_R & U_EN & U_IPI \\
\hline 1 & 0 & 1 & 31 & 67 & 0 & 0 \\
\hline 6 & 6 & 1 & 23 & 67 & 1 & 2 \\
\hline 12 & 8 & 1 & 22 & 65 & 2 & 2 \\
\hline
\end{tabular}

U_EN Variance decomposition

\begin{tabular}{|c|c|c|c|c|c|c|}
\hline & I_IPI & EMBI & U_CPI & U_R & U_EN & U_IPI \\
\hline 1 & 2 & 1 & 54 & 3 & 40 & 0 \\
\hline 6 & 2 & 1 & 52 & 3 & 38 & 4 \\
\hline 12 & 2 & 1 & 52 & 3 & 38 & 4 \\
\hline
\end{tabular}

U_IPI Variance decomposition

\begin{tabular}{|c|c|c|c|c|c|c|}
\hline & I_IPI & EMBI & U_CPI & U_R & U_EN & U_IPI \\
\hline 1 & 1 & 0 & 2 & 0 & 1 & 97 \\
\hline 6 & 2 & 0 & 3 & 1 & 1 & 92 \\
\hline 12 & 3 & 0 & 3 & 2 & 2 & 91 \\
\hline
\end{tabular}

Brazil

B_CPI Variance decomposition

\begin{tabular}{|c|c|c|c|c|c|c|}
\hline & I_IPI & EMBI & B_CPI & B_R & B_EN & B_IPI \\
\hline 1 & 0 & 0 & 100 & 0 & 0 & 0 \\
\hline 6 & 6 & 4 & 49 & 39 & 1 & 1 \\
\hline 12 & 6 & 4 & 49 & 39 & 1 & 1 \\
\hline
\end{tabular}

B_R Variance decomposition

\begin{tabular}{|c|c|c|c|c|c|c|}
\hline & I_IPI & EMBI & B_CPI & B_R & B_EN & B_IPI \\
\hline 1 & 3 & 2 & 1 & 94 & 0 & 0 \\
\hline 6 & 12 & 2 & 2 & 81 & 2 & 1 \\
\hline 12 & 12 & 2 & 2 & 81 & 2 & 1 \\
\hline
\end{tabular}

B_EN Variance decomposition

\begin{tabular}{|c|c|c|c|c|c|c|}
\hline & I_IPI & EMBI & B_CPI & B_R & B_EN & B_IPI \\
\hline 1 & 0 & 13 & 16 & 2 & 69 & 0 \\
\hline 6 & 2 & 16 & 12 & 22 & 48 & 0 \\
\hline 12 & 2 & 17 & 12 & 22 & 48 & 0 \\
\hline
\end{tabular}

B_IPI Variance decomposition

\begin{tabular}{|c|c|c|c|c|c|c|}
\hline & I_IPI & EMBI & B_CPI & B_R & B_EN & B_IPI \\
\hline 1 & 4 & 1 & 35 & 0 & 0 & 59 \\
\hline 6 & 6 & 2 & 34 & 3 & 0 & 55 \\
\hline 12 & 6 & 2 & 34 & 3 & 0 & 55 \\
\hline
\end{tabular}

